\title{
An assessment of water shortages and coping mechanisms of Harare residents: A case of Msasa Park and Dzivaresekwa Extension.
}

\author{
Lilian Chaminuka ${ }^{1}$, Taurai D. Nyatsanza ${ }^{2}$ \\ ${ }^{I}$ (Counselling Department, Zimbabwe Open University, Zimbabwe) \\ ${ }^{2}$ Centre for Student Management, Zimbabwe Open University, Zimbabwe)
}

\begin{abstract}
Water shortages have of late caused many health problems as people resort to unprotected water sources. This research study assessed water shortages and coping mechanisms of Harare residents in Zimbabwe. The study was carried out in Msasa Park and Dzivaresekwa Extension suburbs. Coping mechanisms used by the residents during the time of water shortages were identified. Multiple sources of evidence were provided by respondents from the two suburbs. Instrument triangulation was used to add authenticity to the research findings. Convenient sampling and snowballing of 40 residents and 10 councilors was used to draw respondents from the whole population.Findingsshowed that residents went up to more than a month without clean tap water.Respondents were aware of the causes of water shortages. Some respondents from Msasa Park had home-made wells on their households whilst respondents from Dzivarasekwa relied on community boreholes.Residents used buckets and dishes for harvesting rainwater. Recommendations were thatcity authorities should make a roaster for water cuts. Ward councilors should hold developmental meetings on a regular basis to clarify and assiston issues concerning the residents' welfare. There was need to regularly service community boreholes so that residents would continuously have safe and clean water.
\end{abstract}

Keywords: Improved water source,Personal hygiene,sanitation,ward Councillor,water supply,

\section{Introduction}

The availability of safe and clean drinking is a basic necessity for all living human beings. The Accra Declaration (2001) affirms that water is a fundamental human right, essential to human life to which every person, rich or poor, man or woman, child or adult is entitled. Thus, water is one of the most important of all natural resources. It is vital for all living organisms and plays a central role in human health, food production and general economic development. This is aptly captured in the South African Government's White Paper (1994:1) on Water Supply and Sanitation policy which says:

"Water is central to development. A small amount is essential for people's physical survival. Beyond this, a limited amount is needed for basic personal hygiene and household uses. In more affluent countries, water is used as a luxury, for garden and swimming pools".

This statement implies that there should be a minimum amount of water that constitutes a basic human right. There appears to be no consensus on what that amount is. The South African Government White Paper (1994:15) considered 25 litres per person per day as the "minimum required for direct consumption for preparing food and for personal hygiene". On the other hand, WHO and UNICEF (2000), in the Global Water Supply and Sanitation Assessment 2000 Report, defined reasonable access to an improved water supply as the availability of at least 20 litres per person per day from a source within one kilometer of the user's dwelling.

On the use of average usage, Shikiomanov (2000) observed that domestic water consumption represented only $2 \%$ of the global total. It was also noted that a flow of one litre per second was enough to meet the domestic water requirements of about one thousand persons. This translates to an average usage of about 90 litres per person per day. More recently, UN-Water (2006) noted that water consumption in the United States of America ran as high as 380 litres per capita per day and 129 litres per capita per day in Germany whereas 20 to 30 litres per day was being considered enough to meet human basic needs in developing countries.

Nevertheless, provision of safe, fresh water supplies, therefore, becomes crucial if these important virtues are to be sustained. Confirming this position UNESCO (2003) underscores that water, sanitation and hygiene are intertwined determinants of the water-ill health - poverty spectrum. In this spectrum, water has two basic links to health. Firstly, it conveys pathogenic and chemical pollutants, a role that translates into a healthpromoting mechanism when water is used for purposes of hygiene. Several diseases caused by micro-parasitic pathogens such as trachoma, proliferate where there is lack of sufficient quantities of water for basic hygiene.

Secondly, access to safe drinking water coupled with proper sanitation work best to reducing human health problems. 
Water supply is linked to sanitation and eventually to human health. Water shortages seem to be rife in Harare which is overpopulated due to people who have migrated from the rural areas fleeing economic woes and political violence. These people settle in slums or low-cost backyard accommodation in high density suburbs to seek employment opportunities. However, migratory movements cause rapid population growth which, according to the World Conservation Union (1996), place unprecedented demands on water resources and sanitation facilities.

In what could be construed as panic in a veiled form mainly about population growth, the international community has been quite active in trying to avert a possible water supply crisis. The UN General Assembly in 1980 declared the period 1981 to 1990 as the International Drinking Water Supply and Sanitation Decade (UN, 1995) The Earth Summit, otherwise known as the United Nations Conference on Environment and Development (Rio De Janeiro, Brazil, 1992), also adopted Agenda 21 which made detailed recommendations for changing patterns of behavior which cause ill-health in humans and stress to the environment. The action plan included the prevention of air and water pollution (UN, 1995). March 22 is also commemorated as World Day for Water.

The current thrust is to work towards the achievement of Millennium Development Goals (MDGs). In that respect, the period from 2005 to 2015 is regarded as the International Decade for Action (WHO, 2010).

Goal 7 aims at halving by 2015 the proportion of people without sustainable access to safe drinking water and basic sanitation. The combination of safe drinking water and hygienic sanitation facilities is a precondition for success in the fight against poverty and hunger, HIV and AIDS and Malaria, child mortality, gender inequality and empowerment of women. According to WHO (2010), the MDG target means raising the global drinking water coverage from $77 \%$ in 1990 to $88.5 \%$ in 2015.

It is for this significant role of water in human welfare and health that this study has been necessitated. After assessing water shortages and coping mechanisms by Harare residents, appropriate recommendations shall be made to principally help the affected population. It is hoped also, that the research findings shall assist to bridge the communication gap between Harare City Fathers and the city residents. The donor community and well-wishers are also expected to get a glimpse of the plight of these disadvantaged people, assisting wherever possible.

\subsection{Statement of the Problem}

The City of Harare Municipality makes frequent water cuts throughout the city, thereby creating water shortages. Some Harare residents have resorted to digging shallow wells for water supply, pit latrines for faecal excreta disposal and open spaces for garbage disposal. As such questions arise as to whether coping mechanisms the affected residents use in order to manage their day to day activities in the home are not creating more problems hence an assessment of the water shortages and the coping mechanism.

\subsection{Objectives of the study}

1.3.1 Main Objective

To assess the causes and extent of water shortages and coping mechanisms used by affected residents in Harare.

\subsubsection{Specific Objectives}

The following objectives guided the study:

To establish the extent of water shortages and subsequent problems.

To identify coping strategies adapted by residents as a result of water shortages.

To evaluate the community's perceptions, attitudes, behaviours and practices as a result of water shortages.

To find out the communication channels between the community and the City Authorities.

\subsection{Research questions}

The following research questions guided the study:

To what extent were water shortages affecting residents of Harare?

How were the residents coping with the water shortages?

What were the residents' knowledge levels, perceptions, attitudes, behaviours and practices on the effects of water scarcity on hygiene, sanitation and health?

Which communication channels existed between communities and city authorities?

What recommendations could be made to alleviate water shortage problems?

\subsection{Assumptions}

Water supply in Harare is inadequate.

Inadequate water supply is compounded by the existing socio-economic problems in Zimbabwe and high population growth rate. 
Cases of ill-health are prevalent due to unsafe alternative water sources.

\subsection{Significance of the study}

The study is intended to benefit the inhabitants of the city of Harare by Considerable reductions in public health expenditure by the government and in the costs incurred by households as a result of ill-health or death of family members, shall occur when recommended solution are implemented. The success of the research will assist to confirm earlier studies, thereby benefiting the research fraternity.

\subsection{Delimitation of the study}

The study mainly focused on the unending water crisis that Harare residents were facing. The research therefore targeted Harare residents particularly low-income people who were resident in Dzivarasekwa and residents from medium-density residential Masasa Park.

\subsection{Definitions of terms}

Improved water source: household connection, public standpipe, borehole, protected dug well.

Perceptions: opinions which hopefully are a reasonable measure of attitudes/ real inner feelings.

Personal hygiene: individual cleanliness that includes bathing, washing hands, laundering clothes and washing utensils and dishes.

Sanitation: disposal of excreta

Water supply: supply of water for domestic purposes

\subsection{Abbreviations}

ZINWA $\quad$ - $\quad$ Zimbabwe National Water Authority

WHO - $\quad$ World Health Organisation

UNICEF $\quad$ - $\quad$ The United Nations Children's Fund

RWR $\quad$ - $\quad$ Rooftop Rainwater Harvest

CBD $\quad$ - C Central Business District

\subsection{Introduction}

\section{Review of Related Literature}

Water is an integral part of life on this planet. It is an odorless, tasteless, substance that covers more than three-fourths of the Earth's surface. Most of the water on Earth, 97\% to be exact, is salt water found in the oceans. One cannot drink salt water or use it for crops because of the salt content. Salt from ocean water can be removed, but the process is very expensive. Only about 3\% of Earth's water is fresh. Two percent of the Earth's water (about $66 \%$ of all fresh water) is in solid form, found in ice caps and glaciers. Because it is frozen and so far away, the fresh water in ice caps is not available for use by people or plants. That leaves about $1 \%$ of all the Earth's water in a form useable to humans and land animals. This fresh water is found in lakes, rivers, streams, ponds, and in the ground (Falkenmark et al., 2007).

\subsection{Theoretical Framework}

IWRS Principle 4 states that water has an economic value in all its competing uses and should be recognized as an economic and social good. Within this principle, it is vital to recognize first the basic right of all human beings to have access to clean water and sanitation at an affordable price. Managing water as an economic good is an important way of achieving efficient and equitable use, and of encouraging conservation and protection of water resources. As soon as water is collected from a source, it has a price as an economic and social good. The human right to access clean water and sanitation at affordable prices must be recognized, but the scarcity of water demands that economic perspectives should not be ignored. In conditions where water is especially limiting, where supply augmentation is not a feasible option, economic tools should play a larger role in determining how limited water resources should be distributed efficiently and equitably.

The theoretical framework for this study is based on principle 4 and the systems approach. This theory was selected because it recognizes the individual components as well as the linkages between them, and that a disturbance at one point in the system will be translated to other parts of the system. Sometimes the effect on another part of the system may be indirect, and may be damped out due to natural resilience and disturbance.

Sometimes the effect will be direct, significant and may increase in degree as it moves through the system. The systems approach will elicit views, beliefs, attitudes of the community and the city authorities and how they function interdependently. 


\subsection{Water Scarcity}

According to Falkenmark et al., (2007); Appelgren, (1998) water scarcity is viewed as lack of water in relation to water requirements. Two forms of scarcity are often identified namely, physical (or environmental) and structural water scarcity. Physical scarcity refers to deficits in the natural availability of water and is a function of a combination of natural attributes, such as climate, hydrology, geomorphology, soils and vegetation, as well as human-induced physical modifications of these. On the other hand, structurally-induced water scarcity relates to the political-economy of resource allocation and the attendant institutional frameworks, structures and procedures for water governance, management, use and development. Distinction is made between 'water shortage', 'water scarcity', 'water stress' and 'water security'.

According to Appelgren (1998), the term 'water shortage' is used to describe an absolute shortage where levels of available water do not meet certain defined minimum requirements. The actual quantity that determines a per caput minimum may differ from place to place. 'Water scarcity' is a more relative concept, which describes the relationship between demand of water and its availability. Such demand may vary considerably between different countries and different regions within a country. 'Water stress' is the symptomatic consequence of scarcity, which may manifest itself in a number of ways, such as increasing conflict over sectoral usage, a decline in service levels, crop failure and food insecurity. Finally, 'water security' refers to a situation of reliable and secure access to water over time. It does not equate to constant quantity of supply as much as predictability, which enables measures to be taken in times of scarcity to avoid stress.

\subsection{Water and Sanitation}

According to Barnhart and Barnhart (1988) sanitation is the act, fact or process of improving health condition and thereby water is an essential resource for life and good health to improve on sanitation. A lack of water to meet daily needs is a reality today for one in three people around the world (WHO, 2008). WHO (2008) more than 3.4 million people die each year from water, sanitation, and hygiene-related causes and nearly all deaths, 99 percent, occur in the developing world.

In the same vein Grant and Bimha (1984) posit that water shortage has negative effects on the social life of human beings especially women. The reason women are the most affected is that on a daily basis women are often main actors in the management of household environmental resources. Some women go with their small children to the water vendor and stay the whole day waiting for their turn. The children cry all day of hunger and the scorching sun, but getting water is the most important thing at that moment.

The shortage of water facilities and portable clean water in most communities around Zimbabwe has caused untold suffering for most Zimbabwean women and children (Associated Press, 2008). According to Associated Press, (2008) it is not news that women wake up at 4am in most high density areas in Harare such as Budiriro, Glen Norah, Tafara and Mabvuku to fetch water from boreholes. This water is obviously for men, women and children who will be going to work and school. Long queues can be seen as early as 4am for the water and it takes almost 30 minutes for a 20 litre bucket to be full. The whole process which is then repeated around lunchtime and in the evening up to at times around midnight is cumbersome and equally exhausting because of the energy needed to pump the water from the borehole.

WHO and UNICEF (2000), in the Global Water Supply and Sanitation Assessment 2000 Report, defined reasonable access to an improved water supply as the availability of at least 20 litres per person per day from a source within one kilometer of the user's dwelling. Despite the pegged amount of water per day, in a research in Kenya WHO (2008) reported that at the water vendor, it doesn't matter what is the size of your family. Families are just given five jerry cans of 20 litres each and they are expected to use it until after 10 days when they can return for more.

"When I finish my water, which I always do before the end of the 10 days because my family is large, we buy from people who hawk water. They sell one 20 litre container for 50 shillings [US\$0.54], which is very expensive but there is little I can do. At times, you end up using money meant for food to buy water because even if you have food, you can't cook it without water".

Hug (2009) posits that the outbreak of cholera in Zimbabwe was inevitable following long periods of most urban and rural homesteads going without clean and safe drinking water and inadequate treatment of sewage. According to a study by Hove and Tirimboi (2011) Harare water utility was failing to provide its consumers with continuous running tap water. Some of the residents were spending day hours without tap water. Results indicated that slightly above fifty percent (50.4\%) of the Harare residents had a 24 hour service and thirty-seven percent (37\%) had less than 24 hour service but with varying durations. Other areas such as Mabvuku and Tafara in Harare have gone for years without running water (Hug, 2009).

Mangizvo and Kapungu (2010) in a research study reported that Kadoma had also experienced serious water rationing as a way to balance the sharing of this limited resource among all the suburbs in the town, bringing a great inconvenience to residents. Kadoma suburbs have experienced serious sewage blockages. This was due to the reduced water flow in the system, which presented great potential for disease outbreak. 
According to Jonga and Chirisa (2009) during one of the numerous water cuts in Harare, Zimbabwe National Water Authority (ZINWA) said it had run out of purifying chemicals and feared contaminated water would spread a cholera epidemic that has claimed hundreds of lives in 2008. In Mabvuku, a suburb where residents have dug shallow wells in open ground, people say they know unboiled water can make them ill, but that they have no choice.

Zimbabwe experienced a cholera outbreak in 2009 and the principal cause of the outbreak was the lack of access to safe water in urban areas and communities (WHO, 2008). The Zimbabwean cholera outbreak began in August 2008, swept across the country and spread to Botswana, Mozambique, South Africa and Zambia (Hines 2008). A unique feature of Zimbabwe is that its two main cities are located on watershed divides, which means that the water draining out of the city flows into the drinking water sources, all of which are physically located downstream of these return flows (CSIR, 2008).

Thornycroft, (2008) indicated that the cholera outbreak was exacerbated by the collapse of the urban water supply, and garbage collection systems, along with the onset of the rainy season leading to faeces with cholera bacteria being washed into water sources, in particular public drains, as well as providing readily available but contaminated water.

In a study by Henderson (2000) Dzivarasekwa Extension and Porta Farm it was found out that none of the settlements have adequate sanitation, in stark contrast to formal urban areas in Harare where coverage rates for flush toilets is ninety-four percent (94\%). Residents stated that communal latrines are too far away from their houses and have no lighting, making them impossible to use at night. Dzivarasekwa Extension and Hatcliffe Extension do not have latrines at their respective schools.

In the same study residents reported having adequate water supply, although informants also complained of long queues when water points are down and of low pressure at communal taps. Hatcliffe Extension had only four boreholes working out of a possible 14. Residents at Hatcliffe Extension, therefore, endure long queues at water points and spend one hour or more fetching water at the expense of other chores and income-generating activities Henderson (2000).

\subsection{Causes of Water Shortages}

According to a study by Mangizvo and Kapungu (2010) aging equipment plays a role in water shortage. Equipment in the water provision system is dilapidated as a result of old age. The pump equipment has outlived the efficiency of its design and, as a result, the city council is incurring huge maintenance costs to keep them functional. Due to obsolete equipment, the water treatment plant is producing an average of $12,000 \mathrm{~m} 3 /$ day instead of at least $18,000 \mathrm{~m} 3 /$ day.

In the same study by Mangizvo and Kapungu (2010) there are extensive leakages along the main pipe line that supplies water to the city from the water works. This resulted in the loss of approximately 30 percent of treated water. Water bursts were also being experienced in the oldest reticulation mains feeding the residential areas. According to Chigumira and Mujere (2009) the water system in had several underground leakages and small leak was estimated to put to waste more than 500,000 liters of water per year. These were all attributed to the age of the pipes. The aging equipment compromises the efficiency of the water supply system, meaning that water shortages were becoming a regular occurrence in the city of Harare.

Another cause of water shortage is attributed to the power outages. Zimbabwe has been experiencing serious power shortages, which have resulted in power cuts, which have negatively affected the supply of water.

The magnitude of the problem has worsened in Harare, as the water works could go without electricity for periods ranging from 6 hours to 18 hours on a daily basis (Mangizvo and Kapungu, 2010). Chigumira and Mujere (2009) revealed that power outage problem started manifesting in Kadoma in 2005. The Zimbabwe Electricity Supply Authority has not been able to dedicate a power line to the water pumps to avert water problems, yet water is a key component for human wellbeing. Load shedding has been on the increase in the recent past.

The municipality could not raise its own foreign currency, so it depended on the Reserve Bank of Zimbabwe. The central bank was, however, burdened with other responsibilities, such as procuring much needed food for the country, which was experiencing recurrent droughts. The council could not raise the foreign currency from ratepayers as, during that time, the Zimbabwe dollars was the official currency. Foreign currency was necessary for importing spare parts, as well as water treatment chemicals (Mangizvo and Kapungu, 2010).

The President of Zimbabwe in his address to the opening of the Second Session of the $7^{\text {th }}$ Parliament of Zimbabwe referred to the problem of water. President Mugabe in his speech to Parliament noted thus:

"Reliance on middlemen in the procurement of water treatment chemicals has been a major cost driver in the provision of water. To obviate this challenge, Government will centralize the procurement of water treatment chemicals. Furthermore, programmes to develop and boost availability of the country's water resources through the rehabilitation and upgrading of urban and rural water supply will continue. A Statutory 
Instrument will be put in place to render it mandatory for borehole drillers to register and operate on the basis of permits so as to ensure compliance with minimum standards".

\subsection{Coping Strategies}

During water shortages residents adopted to various coping strategies notably the use of ground water which according to Water Act is illegal in high density areas. In low density areas residents drilled boreholes without permission. Some residents have had to walk long distances and queue the whole day to get water from the surrounding farms and low density areas (Baietti, Kingdom and Ginneken, 2006).

As a means of coping strategy residents in Harare resort to shallow dug wells. According to a study in Harare by Mangizvo and Kapungu, (2010) residents have dug shallow wells from which they draw water for various uses. These wells, instead of bringing relief to the residents, have become a health hazard. Most of the wells are not protected, hence the runoffs after a storm collected in them. Given that Harare has experienced serious sewage bursts, raw sewage seems to have found its way into some of the wells hence the hazards in health.

Hunt (2006) posits that dug wells have a large diameter and expose a large area to the aquifer. These wells are able to obtain water from less-permeable materials such as very fine sand, silt, or clay. Disadvantages of this type of well are that they are shallow and lack continuous casing and grouting, making them subject to contamination from nearby surface sources, and they go dry during periods of drought if the water table drops below the well bottom.

Aroka (2010) carried out a study in Kenya on harvesting of the rainwater. Rainwater harvesting involves the diversion, collecting, storage, usage, and management of runoff through various schemes and as sustainably as possible, in order for the water to be used for domestic, livestock, irrigation and/or commercial purposes. In practice this would include for example managing water in dams, shielding soils to prevent extensive evaporation, storing rainwater in tanks, or collecting rainwater from roof-tops.

Rainwater harvesting is also being done in Mabvuku-Tafara in Harare. According to Dube (2011) of the Standard Newspaper a number of households in Mabvuku and Tafara have installed water harvesting equipment with assistance from an American Non-Governmental Organisation (US Aid). The residents collect rainwater from their roof tops through the installation of tanks and other containers to collect the natural water.

Once the water is collected it is stored it 20 litre plastic containers for future use. Though the method offers temporary relief and also available during the rainy season, it is the best in terms of clean and safe water.

Petersen (2007) supported the use of tanks since they are one of the most typical means of collecting rainwater and have a long global history. These are tanks built in connection to tin-roofed buildings (mainly public buildings such as schools) with rainwater flowing in via gutters. They have a capacity of 50000 litres when full, and keeps water cool and relatively contaminant-free. They come in different shapes and materials, for instance cement, brick, iron sheet, and polyethene. According to Emerald Hill School for the Deaf leaflet (2008), they collect rainwater from the rooftops into large tanks for use by school children during the time of water and power shortage. The school also boost of a borehole, which requires power to pump water. During water and power cuts it becomes a double jeopardy, since the school lack the capacity to pump underground water.

During the just ended 2012 ZANU PF Conference in Gweru the President of Zimbabwe called on relevant authorities to find ways to harness and harvest rain water as a way of alleviating hunger and poverty as well as water shortages (Herald 10 December 2012). The benefits of rainwater harvesting include access to relatively safe, clean water at local points, and sustained water demands in times of precipitation failures.

Rainwater harvesting reduces pressure on surface- and groundwater and also contributes to the replenishment of groundwater. In addition it promotes gender equity and female empowerment as it relieves the chore of collecting water from afar for many rural women. Rainwater harvesting can be done in single households or as a joint community venture. The selling point is the systems simplicity in terms of construction, usage and maintenance coupled with a reasonable price (Malesu et al. 2007).

In Nyanga a resort area in Zimbabwe residents were turning to the mountain water as the water shortages takes its toll. According to The Standard of December 16 to 22, 2012 the small town could go for more than a week without tape water, making the weir the only reliable source. Many households and businesses, including hotels are using water pipes to draw that free water to their properties. They are convinced that the water is safer to drink than water they get from the council.

The Water Wheel March/April 2008 reported that water shortages had been a result of leaking pipes which has resulted in high water losses. In Brisbane, Melbourne, Sydney and Perth all in Australia, ten percent or more that 155000 megalitres is lost from urban water systems annually (Rudd, 2007). This volume he urges, is equivalent to 77500 Olympic sized swimming pool. More so the infrastructure has become old, dilapidated and rusty which has resulted in major water losses, thus most of the time people run out of water. 


\subsection{Communication Channels}

Harare Residents Trust (HRT) Communications Officer Mazorodze (2012) laments that service delivery should be viewed as a three-tier approach involving Central Government, local government and the consumers, the citizens, the electorate, who are the residents. Central government is represented by the lead Ministries, Rural and Urban Development, Healthy and Child Welfare among others. The citizens who pay for the services rendered by local authorities are unfortunately being deliberately marginalized by the authorities.

Despite having set the Help Desk City of Harare lacks the capacity to take action on reported problems of water shortage. According to Bin-It Director Fungai Chiposi on social network:

"I took the initiative of cleaning our Central Business District (CBD) and I record and make calls to the Harare Municipality of all water leaks through their Help Desk. The response to the water leak is often slow and treated water which was meant for the residents is wasted" (Bin-It 2012).

Harare Water Director Engineer Christopher Zvobgo in an interview with the Zimbabwe Herald of 25 July 2012, indicated that Harare Metropolitan requires 1200 million litres a day. Whittling supplies to around 311 million litres means only a few residents have access to water. About 45 percent of the treated water is lost either through leaks or thefts. The Director urged Harare residents to report any water leaks they may come across, so that the Harare Municipality takes action.

City of Charles (2012) in Adelaide of Australia posit that the Civic Centre is the key contact point for many of our interactions with residents, with some of our team members serving people across both the front desk and via phone enquiries. These staff members can now see on their computer screens how many customers are waiting to be served, and which colleagues are available to help, which makes it much easier to balance their workload.

Protests by residents over the issue of water shortages are rife mainly in developing world. The residents' complaints are not taken seriously by the city fathers. In Zambia residents from Kwacha a Central Business District residential area staged demonstrations over the issue of water shortages and they intend to impeach their Member of Parliament (Mail Online, 2012). Living without water and power for a fortnight angry Gurgaon residents from India hit the streets, bring traffic in the busy Gurgaon Expressway to a standstill. (Mail Online, 2012).

The Times of India of 25 May 2012 reported that in another protest in Gurgaon residents have alleged that the developer had failed to meet the demands forcing them to depend on private tankers, the company has expressed its helplessness claiming it is not getting enough canal water to meet the requirement. The developer had issued a letter to the Gurgaon Citizen's Council, a residents' organisation stating how they were facing water supply problems from Haryana Urban Development Authority.

IRIN an online news agent on 27 July 2010 reported that thousands of people in Egypt, Africa's second most populous country have taken to the streets in recent months to protest against water shortages. The protests have also spiraled to Harare. Harare residents are planning a series of demonstrations to protest against the worsening water shortages even after the council admitted that it was overwhelmed by the problems (The Standard 30 Oct 2011).

\section{Methodology}

In this study multiple sources of evidence were provided by respondents from different residential locations that in Dzivarasekwa Extension and Msasa Park. This design has been used in similar circumstances by many researchers including Facius (2008) who carried out a study on water scarcity in Tanzania. Water scarcity problems are real-life situations and any common reader will be able to understand what it means to spend a day without water (Soy, 1997).

\subsection{Target Population}

The population of this study was made up of all household leaders in Dzivarasekwa Extension and Msasa Park. Household leaders included parents and adult informants. Councilors from the wards were also respondents representing the city authorities.

\subsection{Sampling}

Convenient Sampling Method was employed to come up with 20 household leaders who become part of the sample. Household leaders did not necessarily mean home owners, since some residents had tenants living at the same house. Thus, the researchers visited the district offices in Dzivarasekwa Extension and Msasa Park on separate days. The first twenty people to visit the district offices to pay rates were automatically included in the study. On selecting 10 local area leaders from Dzivarasekwa Extension and Msasa Park the snowball sampling method was used. Only ward councilor was selected. 


\subsection{Research Instrument}

Three instruments for data collection were used, which were the questionnaire, interview guide and observation. The questionnaire was the major instrument and it was administered to the residents of both areas of the study, while interviews were conducted with the community leaders. Observations were used to observe the consequences of water shortage as well as the coping strategies that were being used by the residents.

\subsection{Data Analysis}

Theresearch study was a case study but qualitative in nature, as such qualitative data analysis was used. The bases of data analysis were the research questions, thus the analysis themes emerged from the research questions. Under each research question responses from residents' questionnaires and local area leaders' interviews related to the question were given. The analysis was made simple as the researcher first sorted the data from all instruments into research question categories. The narrative analysis given also included the actual words as given by the respondents. However, for the sake of clarity and precision, some descriptive statistics were used in tables and graphs.

\section{Data Analysis and Presentation}

TABLE 1: Participating Residents' representation by gender

\begin{tabular}{|l|l|l|l|l|}
\hline \multirow{2}{*}{ Sex } & Dzivarasekwa Residents & \multicolumn{2}{l|}{ Msasa Park Residents } \\
\cline { 2 - 5 } & Frequency & $\mathbf{\%}$ & Frequency & \% \\
\hline Male & 5 & 25 & 8 & 40 \\
\hline Female & 15 & 75 & 12 & 60 \\
\hline Total & $\mathbf{2 0}$ & $\mathbf{1 0 0}$ & $\mathbf{2 0}$ & $\mathbf{1 0 0}$ \\
\hline
\end{tabular}

Findings in Table 1 above show that women constituted $75 \%$ in Dzivarasekwa Extension and $60 \%$ in Msasa Park were respondents. The number of male respondents in Msasa Park constituted $40 \%$, whilst in Dzivarasekwa they were only $25 \%$. The high number of women as respondents showed that most women were the custodians of water management in the communities and more women were found in the communities under study.

In Dzivarasekwa Extension a ward had an estimated population of between 10000 to 15000 people standing at a frequency of $3(60 \%)$, whilst in Msasa Park a ward has an estimated population of less than or equal to 7000. One ward in Dzivarasekwa Extension had less than 10000 people and the other had more than 15000 people. It was evident that there were more people living in Dzivarasekwa Extension as compared to Msasa Park and this showed that there was more water usage in Dzivarasekwa Extension than Msasa Park. The estimate number per ward given by ward Councillors represented the population not households. The Census of 2012 indicated that in ward 39 there was a total population of 24000 people and ward 40 had a total of 45000 people.

\section{Extent of water shortages}

TABLE 2: Number of people per household

\begin{tabular}{|l|l|l|l|l|}
\hline $\begin{array}{l}\text { Number of People per } \\
\text { Household }\end{array}$ & Dzivarasekwa & Msasa Park \\
\cline { 2 - 5 } & $\mathbf{F}$ & $\mathbf{0}$ & $\mathbf{F}$ & $\mathbf{\%}$ \\
\hline $1-2$ people & 0 & 0 & 6 & 30 \\
\hline $3-4$ people & 2 & 10 & 11 & 55 \\
\hline $5-6$ people & 7 & 35 & 2 & 10 \\
\hline 7 or more people & 11 & 55 & 1 & 5 \\
\hline Total & $\mathbf{2 0}$ & $\mathbf{1 0 0}$ & $\mathbf{2 0}$ \\
\hline
\end{tabular}

The findings in Table 2 above indicate that 55\% households of Dzivarasekwa had 7 or more people, whilst the same number of households from Msasa Park which is $55 \%$ had between 3 and 4 people per household. Dzivarasekwa's high number of people in the eleven households can be explained by the residential area being of low socio-economic status. Dzivarasekwa Extension was a high density residential area it was characterised by high number of people per household due to extended families. Another factor in Dzivarasekwa, households was also characterized by increased numbers of people due to a lot of sub-letting of rooms within the house. A different scenario was evident in the Msasa Park; households only accommodated one family per household. Findings also indicated that in Dzivarasekwa Ext 7 households had 5-6 people (35\%) which were still higher than the highest number of people living in a single household in Msasa Park. A representation of 2 households of the respondents in Dzivarasekwa showed that 3-4 people inhabited a home, whilst in Msasa Park 6 households had as little as1-2 people (30\%). Only 2 households in Msasa Park had 5-6 people (10\%) and 7 and more people could be found represented in a single household (5\%). This particular household had a couple lodging in the main house. 


\section{Number of litres used per day by residents}

Respondents from Dzivarasekwa Ext (65\%) used more than 60 litres per day, whilst 50\% from Msasa Park used $21-40$ litres per day. The difference in the amount of water used could be explained by the differences in the number of people living per household as well as the total number of people per ward. Furthermore, 30\% of respondents from Msasa Park used less than 20 litres of water per day probably because of the little number of people characterizing the households. In Dzivarasekwa only $25 \%$ of the respondents stated that they used between 41 and 60 litres of water per day. The water bills were insignificant since most households spent more than month without taped water, thus they are required to pay for fixed water charge which is mandatory for all households that have piped water delivered at their household at one time or another. Also the amount of water usage depended on availability of manpower to cart the water for daily use. In Msasa park observation showed that a high number of respondents used vehicles to ferry water from the water source and they had a high volume of water conservation.

\section{Period of time without taped water}

Respondents from Dzivarasekwa constituting 55\% spent a month and over without taped water from the Municipality, whilst only 25\% from Msasa Park indicated that they spent the same period of time without tap water. Again, the high numbers of residents in some sections of Dzivarasekwa explain the high percentage of people who went without water for long periods of time. In Msasa Park 35\% indicated that they spent a week or less without water, whilst $15 \%$ of Dzivarasekwa Extension were of the same predicament. The other 30\% and 25\% of Dzivarasekwa and Msasa Park respectively, indicated that they spent a fortnight without taped water. The absence of water for at least a week and over was being experienced by a large number of people in both residential areas.

Councilors from Dzivarasekwa indicated that they had an estimate of between 10000 to 15000 people in their wards, whilst those from Msasa indicated that they had less than 7000 people in their wards.

\section{Waiting duration to get water}

The majority of residents from Msasa Park constituting $75 \%$ indicated that they waited in any water source queue to get water for less than an hour, whilst from Dzivarasekwa $55 \%$ indicated that they waited for more than 2 hours in a queue to get water for household use from a water source. The other $25 \%$ from Dzivarasekwa indicated that they waited for up to 2 hours, whilst those from Msasa Park who waited for up to 2 hours constituted 15\%. Only 25\% from Dzivarasekwa indicated that they waited less than an hour to get water.

The time spent by people waiting for their turn to get water form a source was too long and impacted adversely on other socio-economic activities for the residents.

\section{Time for fetching water.}

Respondents from both Dzivarasekwa and Msasa Park constituting 50\% went to fetch water anytime they wanted without any problems, whilst $20 \%$ woke up around 4 am to prepare to go and get water for household use. This is the group of people who had to fetch water and prepare to go to work and school. Only $10 \%$ indicated that they went to fetch water any time after 6 am and these people represented those who spend the day at home. During the dry season when the water was at its lowest, some youths spend the night in the queue only to sell their places to those who came late, these youths also horde water during the night which makes it difficult for some of the residents who came to the borehole and found it already dry. They were left with no option but to buy water from these illegal water vendors at US\$1 per 20 litres.

On the implications brought about by the lack of water they all councilors agreed that water shortage had triple hygienic effects in the house. Women were reported as the main players who suffered due to lack of water, the reason being that they fend water for the whole family. They spent a lot of time looking for the rare commodity especially in Dzivarasekwa Ext

\section{Interpretation}

The findings on water required per day clearly showed that there was water shortage in Dzivarasekwa Ext and Msasa Park since a person required at least 20 to 25 litres of water per day. The findings were in line with The South African Government White Paper (1994:15) that considers 25 litres per person per day as the "minimum required for direct consumption for preparing food and for personal hygiene". On the other hand, WHO and UNICEF (2000), in the Global Water Supply and Sanitation Assessment 2000 Report, defined reasonable access to an improved water supply as the availability of at least 20 litres per person per day from a source within one kilometer of the user's dwelling. 


\section{One Dzivarasekwa resident said:}

"It is impossible for me to get more water at the community borehole especially during the dry months of August - September because the water supply will be low and demand for water is high. We are then limited to a 20 litres per person. I have a big family and one 20 litres cannot sustain the family chores of 7 people".

The shortage of water facilities and portable clean water in most communities around Zimbabwe has caused untold suffering for most Zimbabwean women and children (Associated Press, 2008). According to Associated Press, (2008) it is not news that women wake up at 4 am in most high density areas in Harare such as Budiriro, Glen Norah, Tafara and Mabvuku to fetch water from boreholes. This water is obviously for men, women and children who will be going to work and school. Long queues can be seen as early as 4am for the water and it takes almost 15 minutes for a 20 litre bucket to be full. The whole process which is then repeated around lunchtime and in the evening up to at times around midnight is cumbersome and equally exhausting because of the energy needed to pump the water from the borehole.

One Msasa Park resident reported that:

"During the dry months one has to wake up very early to manage to draw water from the well, otherwise you will have to go and wait in a long queue at one borehole that is if it's working."

\section{Health effects}

Most of the respondents $70 \%$ indicated that cholera was the most feared health hazard; whist $20 \%$ indicated typhoid as the health factor time bomb. The other $10 \%$ indicated dysentery. All councilors indicated that cholera was the most feared health hazard.

\section{Reasons for water shortage}

From both Dzivarasekwa and Msasa Park $72 \%$ of the respondents indicated that shortage of purification chemicals was the reason behind water cuts. The other respondents indicated water leakages and others who did not know constituted $15 \%$ and $13 \%$ respectively.

Councilors: Results indicated that councilors had inside knowledge better than residents they all reported that water cuts were the effect of shortages of purification chemicals and burst pipes which need replacement.

\section{What explanation is given by the city authorities as the cause of these water cuts?}

All respondents constituting $100 \%$ indicated that the explanation given by municipality was that there was a shortage of purification chemicals.

\section{Are there any water leaks in your residential area?}

All respondents, again, constituting $100 \%$ indicated that there was always water leakage in their respective residential areas.

\section{Interpretation on Knowledge}

Results from the current study show that residents and councilors were aware of the health scare posed by the lack of water. Thornycroft, (2008) indicated that the cholera outbreak was exacerbated by the collapse of the urban water supply, and garbage collection systems, along with the onset of the rainy season leading to faeces with cholera bacteria being washed into water sources, in particular public drains, as well as providing readily available but contaminated water. In a study by Henderson (2000) Dzivarasekwa Extension and Porta Farm, it was found out that none of the settlements had adequate sanitation; in stark contrast to formal urban areas in Harare where coverage rates for flush toilets is ninety-four percent $(94 \%)$. Residents stated that communal latrines were too far away from their houses and have no lighting, making them impossible to use at night. Dzivarasekwa Extension and Hatcliffe Extension did not even have latrines at their respective schools.

\section{One resident from Dzivarasekwa Ext said:}

"The lack of water does not do us any good as a lot of diseases are caused by unhygienic situation, can you imagine that we only flush our toilets once a day as we have to save water. We are family of 6 adults and 5 children the situation is really bad. Sometimes I am afraid of getting sick as what happened in 2008".

\section{Another resident from Msasa Park said:}

"Water shortages trigger a lot more than we can imagine. In 2008 a lot of people died due to cholera because there was no adequate clean water as people were forced to get water from unprotected wells. The Harare Municipality should help us by providing tapped water more often". 
The current study found out that shortage of water purification chemicals was the main cause of water shortage, a point also indicated by ward councilors. Jonga and Chirisa (2009) during one of the numerous water cuts in Harare, Zimbabwe National Water Authority (ZINWA) said it had run out of purifying chemicals and feared contaminated water would spread a cholera epidemic that has claimed hundreds of lives in 2008. In Dzivarasekwa Ext. were some residents had dug shallow wells in open ground, people said that they knew un treated water could make them ill, but that they had no choice as energy to boil water was expensive.

\section{Ward councilor said:}

"One major cause of water cuts was the lack of purification chemicals and late delivery of the purification chemicals. It would be disastrous to provide untreated water to the residents so the only workable solution is to cut the water supply until the availability of the chemicals".

Findings also indicated that water leakages contributed to the water shortage as millions in mega litres of treated water were wasted a fact also concurred by Mangizvo and Kapungu 2010. This resulted in the loss of approximately 30 percent of treated water. Water bursts were also being experienced in the oldest reticulation mains feeding the residential areas. The findings were also supported by Harare Water Director Engineer Christopher Zvobgo in an interview with the Zimbabwe Herald of 25 July 2012, were he indicated that Harare Metropolitan required 1200 million litres a day. Whittling supplies to around 311 million litres meant only a few residents had access to water. About 45 percent of the treated water was lost either through leaks or thefts. The Director urged Harare residents to report any water leakages.

\section{One resident from Msasa Park said:}

"There is a ditch down the road which was a result of pipe burst. It has been like that for several months on and residents nearby often gets water for domestic purpose there. A report has been made to the councilor but nothing has been done".

\section{One councilor said:}

"The problem is that as city council we do not have vehicles to go to every area and fix water bursts, let alone the pipes to replace the ones that burst. The only way is to close that pipe line until we get the materials but that way is not acceptable since it leaves people without water for a longtime".

\section{Coping strategies during water cuts Soures of water during water cuts}

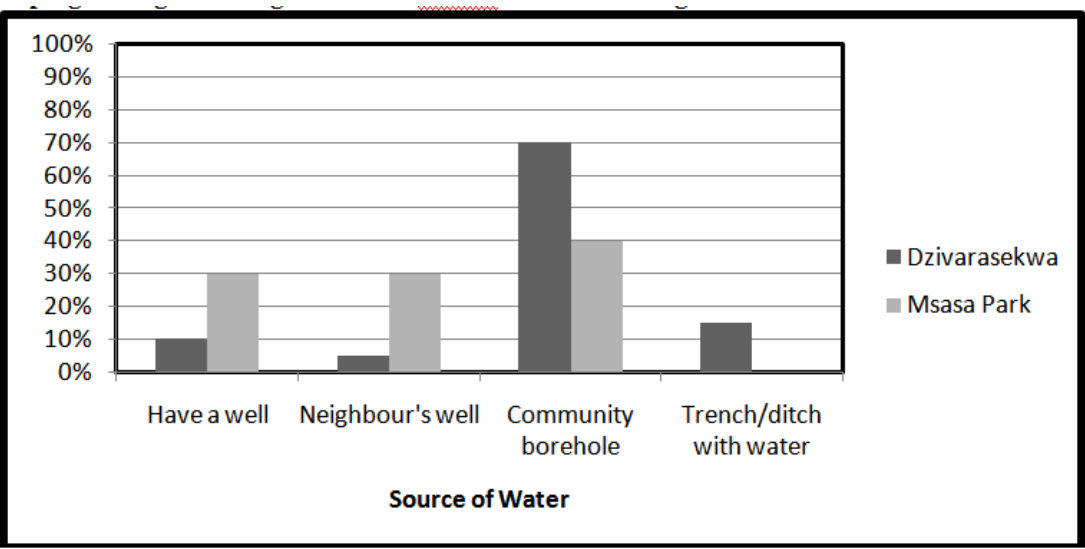

Fig 1: Source of Alternative Water

Findings from figure 1 above show that the $70 \%$ Dzivarasekwa respondents got their water from community boreholes, whilst only $40 \%$ of Msasa Park respondents got water from a community borehole. A sizeable number of Msasa Park residents constituting 30\% either had their own well or they used the neighbour's well. In comparison $10 \%$ of respondents from Dzivarasekwa had their own wells and another $12 \%$ got their water from nearby ditch/trench.

All interviewed councilors said that they had community boreholes in their wards. The Msasa Park councilors reported that a sizeable number of households in their wards had water wells at their residential areas and they often shared with others. According to the councilor the availability of wells in Msasa Park reduced water problems. 
Methods used to harvest the rainwater

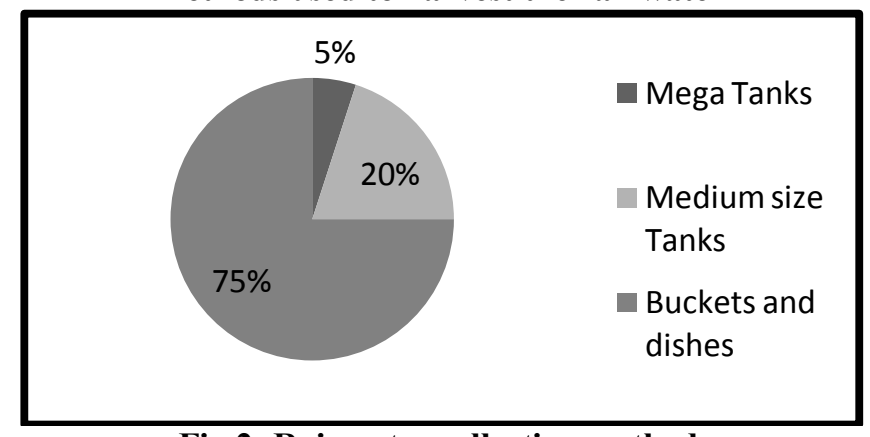

Fig 2: Rainwater collection method

The results from Fig. 2 above show that the $75 \%$ of respondents indicated that they used buckets and dishes to collect rainwater, whilst the other $20 \%$ used medium sized tanks. The other $5 \%$ indicated that they had mega tanks (especially those in Msasa Park).

\section{Quantities of water harvested}

Residents from Dzivarasekwa 65\% and 50\% from Msasa Park harvested 100 litres or less from the rainwater. The other $40 \%$ and $35 \%$ indicated that they harvested between 100 to 500 litres, whilst only $5 \%$ Msasa Park respondents indicated that they harvested more than 1000 litres. It is evident that the small number of people that managed to collect above 1000 litres in Msasa were those people who own larger tanks for water storage.

\section{Interpretation on coping strategies}

As a means of coping strategy residents in Harare resorted to shallow dug wells. According to a study in Harare by Mangizvo and Kapungu, (2010) residents had dug shallow wells from which they draw water for various uses. These wells, instead of bringing relief to the residents, had become a health hazard. Most of the wells were not protected, hence the runoffs after storms collected in them. Given that Harare has experienced serious sewage pipe bursts, raw sewage seems to have found its way into some of the wells hence the hazards in health.

A resident from Dzivarasekwa Ext said:

"We often get our water from the community borehole but as you know public things, it is often not working then after that we are left with no choice but to get water from trenches and other unprotected sources of water such as wells near the river or near swamps".

\section{Another resident from Msasa Park said:}

"We get most of our water from a well, but during the dry months in August our water runs dry. We share the well with other residents who do not have wells of their own, thus the demand is too much. Right now the well is filling up and also the demand is less due to the rainwater people have jerry cans to collect the rainwater".

Aroka (2010) carried out a study in Kenya on harvesting of the rainwater. Rainwater harvesting involves the diversion, collecting, storage, usage, and management of runoff through various schemes and as sustainably as possible, in order for the water to be used for domestic, livestock, irrigation and/or commercial purposes. In practice this would include for example managing water in dams, shielding soils to prevent extensive evaporation, storing rainwater in tanks, or collecting rainwater from roof-tops.

\section{A resident from Msasa Park said:}

"We are grateful especially during this rainy season as we are able to fill our mega tank with rainwater. The rainwater is much safer to drink than the tapped water since we collect it right from the source. Our tank is connecting direct to the roof gutters and we are able to collect as much water as needed".

\section{Communication Channels \\ Representation}

Dzivarasekwa respondents (65\%) indicated that they had their representative leaders, whilst $55 \%$ of Msasa Park said they did not have any representatives. Another $20 \%$ from all respondents were not sure whether they had the representatives or not. Eighty percent of Msasa Park respondents had never bothered at one time or the other tried to seek explanation from the city authorities concerning the water shortages, whilst other $60 \%$ of Dzivarasekwa respondents said they had at one time tried find out the reason for water 
shortages.Dzivaresekwa residents indicated that they had demonstrated at one time or another to city authorities about their displeasure on water shortages. On the other hand, $70 \%$ from Msasa Park had actually never demonstrated their concern at all. Only 30\% from Msasa Park indicated that at some point they tried to show their displeasure. It is evident that the high number of people from Dzivarasekwa who demonstrated found it worthy to do so because it was easy to network and discuss their concerns and find a way forward. Compared to Dzivarasekwa residents from Msasa Park are more affluent and use cars to transport water from nearby or far off water sources.

Results indicate that councilors were the representatives of the Harare Mayor as they had the mandate to meet the people regularly and appraise them on issues pertaining their welfare. Furthermore, councilors had to explain any policy concerning the Harare Municipality to the residents of their respective residential areas.

Findings also indicated that councilors had to see to the property of the council in their respective areas of residents. Councilors were responsible when there were any water leakages as it was their duty to report so that the Department of Works could do some repairs. The councilors also needed to report any vandalism that would have occurred to the council property. All councilors agreed that they acted as a bridge between residents and the municipality as they were there to act as mouth pieces of the residents, thus, all communication had to come through their respective office to be forwarded to the town council for action

\section{Interpretation on communication channels}

Protests by residents over the issue of water shortages were rife mainly in the developing world. It appears the residents' complaints were however not taken seriously by the city fathers. In Zambia residents from Kwacha Central Business District residential area staged demonstrations over the issue of water shortages and they intended to impeach their Member of Parliament (Mail Online, 2012). Living without water and power for a fortnight angry Gurgaon residents from India hit the streets, bringing traffic in the busy Gurgaon Expressway to a standstill. (Mail Online, 2012).

\section{One Msasa park resident said:}

"Why bother by demonstrating, yet we all know that there is nothing the Harare Municipality can do to bring water to our homes. For as long the Ministry of Local Government continues to stifle progress there is nothing that can be done".

\section{Another disgruntled resident from Dzivarasekwa Extension said:}

"We have demonstrated but nothing has changed. We still wake up without tap water. It seems the city fathers do not care about us. As long they collect their rent and rates from us, they seem satisfied. I have realized that it is better not to pay the rates at all."

The results have shown that respondents from Msasa Park do not have community leaders, besides the ward councilors. Only Dzivarasekwa respondents do have a community leadership. It was also found out that respondents from Msasa Park had never at one time sought to be addressed by their ward councilors concerning the water shortages, yet respondents from Dzivarasekwa had at one time or the other sought clarification and understanding on the water shortages in the area.

\section{One respondent from Msasa Park said:}

"Seeking address from these ward councilor is a waste of time because they do not have what it takes to represent the people, they are only there for ornamentation. We do not have any community leaders in our area that I am aware of because the water shortage has become cancerous as there is no lasting solution. If we had such people then they could have resolved the water woes we suffered."

\section{Conclusions made from the study}

\subsection{The extent of water shortage}

The findings have shown that residents go for up to more than a month without clean, potable tap water in the two suburbs under study. Findings also indicated that in Dzivarasekwa Extension the number of people per household was too large as compared to the amount of water used per day. It was also found in the study that residents of Dzivarasekwa wait for more than 2 hours for their turn to get water for domestic use.

Therefore it can be concluded that extent of water shortage for residents of Dzivarasekwa Extension were more acute than in Msasa Park.

\section{Knowledge, perceptions and practices}

Findings from residents' knowledge levels, perceptions, and practices on the effects of water scarcity on hygiene, sanitation and health showed that all residents were quite aware on the effects of water shortages in terms of hygiene, sanitation and health as they all reminiscence the days of the deadly cholera outbreak that 
devastated the country in 2008. Findings also indicate that all respondents were aware of the causes of water shortages as they witnessed many areas where treated water is lost through leakages and burst pipes. Thus, it can be concluded that all respondents were quite aware of the consequences of water shortages and the main cause of these shortages.

\section{Coping Mechanisms}

The question which sought to find out the coping mechanisms used by respondents during long periods of water cuts produced findings that indicated that a few respondents from Msasa Park had protected wells on their households as compared to respondents from Dzivarasekwa who solely used the community boreholes in their local areas or had very shallow unprotected wells. Furthermore, it was found that all respondents took advantage of the rainy season to harvest rainwater through different methods. The use of buckets and dishes was the most common method of harvesting rainwater by all respondents. It was found out that only a handful of respondents from Dzivarasekwa resort to the use of trenches and burst water pipes to get water for domestic purposes.

\section{Communication channels}

On communication channels for reporting the residents' grievances, findings indicated that respondents from Dzivarasekwa had at one time or another demonstrated their frustration caused by water shortage. Results also indicated that respondents from Msasa Park had never at any time, as a group, demonstrated their displeasure on the issue of water shortage. They had never sought to be addressed by their ward councilors. Msasa respondents also do not have any community leaders. Thus, it can be concluded that Dzivarasekwa respondents were aware of communication channels to be followed when they want to air their grievances, yet Msasa Park respondents did not bother about such issues.

\section{Conclusion}

In conclusion, the study generalized that Harare residents experienced water shortages for over a month and this had tremendous effects on their health. These residents were aware of the health risks they were faced with. There was the fear of contracting cholera as the most deadly disease that was common during the time of water shortages. Thus, it is recommended that the City of Harare come up with a sustainable rotational schedule for water for the great Harare. Equitable water rationing might be pragmatic since it is known that the City Council is facing some challenges. This will also make the lives of residents bearable as they will have time for other chores other than fetching water.Harare residents had devised some coping strategies to circumvent the water shortages they faced on a daily basis. It was revealed that residents took advantage of the rains and they harvested the rainwater for domestic purposes using several methods from dishes to mega tanks.

Harare Municipality strengthens its ties with Non-Governmental Organisations (NGOs) and source for larger containers for rain harvesting to enable residents to collect maximum water from the rain for domestic purposes.It is suggested that the Harare Municipality regularize the digging of wells on residential properties.

This helps to ensure that the wells are protected and that they are not of the shallow type. Finally, some residents were not aware of the communication channels to be followed in the event they were aggrieved because residents tended to suffer silently. It is therefore recommended that area councilors should hold developmental meetings with residents on a regular basis to clarify and assist on issues concerning the welfare of residents.

Acknowledgements
Special thanks to the L Matongo and the Institute of Water and Sanitation Harare, Zimbabwe

\section{References}

[1] Appelgren, B and Klohn, W. (1998). Management of Water Scarcity: A Focus on Social Capacities and Options. Land and Water Development Division. Food and Agricultural Organisation of the United Nations, Rome: Italy.

[2] Associated Press (2008) Zimbabwe Faces Water And Cholera Crisis.

[3] Aroka, N. (2010) Rainwater Harvesting in Rural Kenya: Reliability in a Variable and Changing Climate Department of Physical Geography and Quaternary Geology, Stockholm University.

[4] Baietti, A., Kingdom, W., and Ginneken, M. V., (2006), Water Supply and Sanitation Working Notes. Note no. 9,

[5] Characteristics of Well Performing Public Water Utilities, Washington DC, World Bank.

[6] Chigumira, E. and Mujere, N. (2009). Variability Of Urban Water Supply and Demand. In J.

[7] Emerald Hill School for the Deaf leaflet (2008) School Development Project

[8] Falkenmark, M. and Lundqvist, J. (1995) World freshwater problems: Call for a new realism. Background paper for the Comprehensive Freshwater Assessment. Stockholm Environment Institute (In press).

[9] Grant, N.J.H and Bimha, J.M. (1984) English for Zimbabwe Students Book 4, Longman Harare.

[10] Heppner P. P. (1992) Research Design in Counseling. New York: Allyn and Bacon.

[11] Hove, M. and Tirimboi, A. (2011) Assessment of Harare Water Service DeliveryJournal of Sustainable Development in Africa (Volume 13, No.4, 2011) ISSN: 1520-5509Clarion University of Pennsylvania, Clarion, and Pennsylvania. 
[12] Hug, A. (2009). Inside Zimbabwe's Cholera Epidemic. Canadian Medical Association. Retrieved from: www.cmaj.ca, on December 102012 .

[13] Jonga, W. and Chirisa, I. (2009) Theoretical and Empirical Researches in Urban Management, No. 12, August.

[14] Malesu, M. M, Odour, R. A. Odhiambo, J. O. (2007). Green Water Management Handbook, Rainwater harvesting for agricultural production and ecological sustainability. World Agroforestry Centre.

[15] Mangizvo, R. and Kapungu, N. (2010) Urban water crisis in Zimbabwe: Case study of Kadoma. Journal of Sustainable Development in Africa (Volume 12, No.8, 2010) ISSN: 1520-5509

[16] Clarion University of Pennsylvania, Clarion, Pennsylvania

[17] http://whqlibdoc.who.int/publications/2010/9789241563956_eng_full_text.pdf, accessed on Sunday, $6^{\text {th }}$ June, 2010.

[18] Nissen-Petersen, E. (2007) Water from Roofs. ASAL Consultants Ltd.

[19] The Herald (2012) Harare to go dry, says town clerk Wednesday, $25 \quad$ July 2012 Municipal Reporter http://www.herald.co.zw retrieved on Dec 10, 2012

[20] The Herald. (2010). Acute Water Shortages Hit Capital. The Herald (January 22).

[21] The Standard. (2010). Water Shortage Hits Gweru, Harare, Zimbabwe. The Standard (January 16).

[22] Tichaona Sibanda 26 July 2012Bulawayo declares water emergency. http://www.swradioafrica.com

[23] WHO and UNICEF, (2010) Joint Monitoring Programme for Water Supply and Sanitation, 